\title{
EFFECTS OF TREE ROOT COMPETITION ON AVAILABILITY OF SOIL AND PLANT NUTRIENTS, SOIL WATER AND LIGHT INTERCEPTION IN HEDGEROW INTERCROPS WITH DIFFERENT TREE SPECIES IN THE MID-COUNTRY INTERMEDIATE ZONE
}

\author{
W.A.J.M. DE COSTA ${ }^{1+}$ and A.G. CHANDRAPALA ${ }^{2}$
}

${ }^{1}$ Department of Crop Science, Faculty of Agriculture, University of Peradeniya, Peradeniya.

' Natural Resource Management Centre, Department of Agriculture, Peradeniya.

\begin{abstract}
This investigation determines the inter-species differences in root competition exerted by six tree species (Calliandraculothyrsus, Desmodium rarisonii, Flemingia congesta, Gliricidia sepium, Cassia spectabilis and Tithonia diversifolia.) on mung bean (Vigna rudiata) growing as hedgerow intercrops in the mid-country intermediate zone of Sri Lanka. All intercrops had significantly lower plant nutrient $(\mathrm{N}, \mathrm{P}, \mathrm{K})$ contents than sole mung bean indicating significant competition by hedges for nutrients. This was confirmed by increased plant nutrient contents when a $1.5 \mathrm{~m}$ deep trench was cut between hedges and crop rows. Competition was lowest by Gliricidia and highest by Cassia. This was confirmed by soil nutrient analysis at sowing and harvesting of mung bean. All intercrops showed increases of exclaangeable soil $\mathrm{K}$ and available P (except with Gliricidica) during the cropping season. The fraction of incoming radiation intercepted was higher near hedges than in mid-plot indicating competition for light which was highest by Tithonia (greater canopy spread) and lowest by Desmodium and Flemingia (lower canopy spread). Soil water content (SWC) was greater in sole mung bean than in intercrops indicating root competition for water. This was confirmed by increased SWC with trenching. Competition for water was mitigated to some extent by soil water conservation viu. the shading effect of canopies such as Tithonia. Based on the above results, it is concluded that tree roots of hedgerow intercrops exerted significant competition with the annual crop for absorption of nutrients and water. In the present environment, out of the tree species tested, Gliricidia exerted the least competition for nutrients while Tithonia exertied the least competition for water: This information could be used in the selection of tree species for hedgerow intercropping in the mid-country intermediate zone of Sri Lanka.
\end{abstract}

Keywords: Hedgerow intercropping, mung bean, nutrients, radiation interception, root competition

\section{INTRODUCTION}

Competition for above- and below-ground resources is an unavoidable phenomenon in simultaneous agroforestry systems. ${ }^{1-4}$ Corlett et al. ${ }^{5}$ and De Costa and Chandrapala ${ }^{6}$ have shown that interception of incident radiation by hedgerows reduced the light available for the annual crop in the alleys. Moreover, Singh et al. ${ }^{7}$, Szott et al. ${ }^{8}$, Corlett et al. ${ }^{5}$ and De Costa and Chandrapala ${ }^{6}$ have specifically shown that absorption of soil nutrients and water by tree roots reduces the availability of these growth resources to the associated annual crop. However, there is scope for minimizing competition and consequent crop yield reductions by careful choice of 
tree species. In a previous paper, De Costa and Chandrapala ${ }^{4}$ reported significant variation between different hedgerow tree species in their root and shoot competition exerted on mung bean (Vigna radiata (L.) Wilczek) in hedgerow intercropping (HI) systems. The general objective of this investigation was to determine the inter-species variation in root competition for nutrients and water and shoot competition for light and thereby identify tree species suitable for $\mathrm{HI}$ in the mid-country intermediate zone of Sri Lanka. The specific objectives were : (a) To determine the effects of root competition $\left(\mathrm{C}_{\mathrm{r}}\right)$ from different tree species on plant and soil nutrient contents and soil water contents; and (b) To determine the inter-species variation in competition for light by examining radiation interception.

\section{METHODS AND MATERIALS}

The experiment was carried out under rainfed conditions from June to October, 1998 at Pallekelle in the mid-country ( $367 \mathrm{~m}$ above mean sea level) intermediate (rainfall $\left.1400 \mathrm{~mm} \mathrm{yr}^{-1}\right)$ zone $\left(\mathrm{IM}_{3}\right)$ of Sri Lanka $\left(7-8^{\circ} \mathrm{N} \& 80-81^{\circ} \mathrm{E}\right)$ on a moderately well-drained soil belonging to Rhodudults. A detailed description of the experimental procedure is given in De Costa and Chandrapala. ${ }^{*}$ Only the essential details are given here.

The experimental treatment structure was a two factor factorial laid out in a split-plot design. As the main plot factor, there were six HI with six hedgerow tree or perennial shrub species (Calliandra calothyrsus Meissn., Desmodium ransonii (L.) DC., Flemingia macrophylla (Willd.) Merr., Gliricidia sepium (Jacq.) Steud., Cassia spectabilis (L.) DC. and Tithonia diversifolia (Hemsl.) A. Gray) plus a sole crop of mung bean (Vigna radiata (L.) Wilczek) as the control. As the sub-plot factor, there was a trenching (TR) treatment (i.e. $1.5 \mathrm{~m}$ deep trench between hedges and crop rows to prevent lateral extension of roots) and a no-trenching (NTR) treatment.

Measurements: $\mathrm{N}, \mathrm{P}$ and $\mathrm{K}$ contents in mung bean were measured $50 \mathrm{~d}$ after sowing (i.e. at 50\% flowering stage). Plant samples were taken at 30,180 and $360 \mathrm{~cm}$ from hedges and their nutrient contents were analyzed separately. Total $\mathrm{N}$ was measured on samples digested with Conc. $\mathrm{H}_{2} \mathrm{SO}_{4}$ acid using the micro-Kjeldahl method. ${ }^{9}$ Total $\mathrm{P}$ was measured colorimetrically on ashed samples which had been digested with nitric acid. The dry ash method ${ }^{10}$ was used to measure plant $\mathrm{K}$ content.

Major soil nutrient contents (i.e. total $\mathrm{N}$, available $\mathrm{P}$ and exchangeable $\mathrm{K}$ ) and soil $\mathrm{pH}$ were measured at the beginning and end of the cropping season. ${ }^{11}$ Soil samples were taken from both top soil (0-10 cm depth) and sub-soil $(20-40 \mathrm{~cm})$ at 15 , 165 and $345 \mathrm{~cm}$ from hedges. Available soil $\mathrm{N}$ was extracted by $\mathrm{KCl}$ and was determined by the micro-Kjeldahl method. Available P was extracted by $\mathrm{NaHCO}_{3}$ and was determined colorimetrically. Available $\mathrm{K}$ was extracted by ammonium 
acetate and was determined by the flame photometer. Soil water content in top $(0-10 \mathrm{~cm})$ and sub $(20-40 \mathrm{~cm})$ soil was measured gravimetrically at 2 week intervals from sowing up to 10 weeks after sowing of mung bean. Samples were taken at 15 and $200 \mathrm{~cm}$ distances from hedges. The fraction of incoming radiation intercepted ( $f$ ) by the combined canopies of hedges and mung bean was measured in trenched treatments using a pair of tube solarimeters at 2 week intervals from sowing up to 10 weeks after sowing. Measurements of $f$ were made at 15 and $200 \mathrm{~cm}$ from hedges. During each measurement one solarimeter was kept in the open to measure incoming radiation while the other was kept at ground level inside the plot at specified distances from the hedge. Voltage output from solarimeters were recorded and integrated by microvolt integrators. All measurements were made around mid-day (i.e. from $1000 \mathrm{~h}$ to $1400 \mathrm{~h}$ ) and each measurement was done for a period of $15 \mathrm{~min}$.

\section{RESULTS}

Plant nutrient contents: Plant nutrient contents did not show significant $(p<0.05)$ differences or consistent variation with distance from hedges (data not shown). Therefore, the respective nutrient contents were averaged across different distances. Trenching significantly $(p<0.001)$ increased $N$ content in mung bean grown with all tree species (Table 1). Mung bean under Gliricidia and Cassia had the highest and lowest $\mathrm{N}$ contents respectively in both TR and NTR. Only the mung bean with Cassia and Flemingia had significantly $(p<0.05)$ lower $N$ than the sole crop control under both trenching treatments. The rest had plant $N$ contents which were not significantly $(\mathrm{p}<0.05)$ different from that of the control (Table 1). P contents of mung bean in all HI were significantly $(p<0.05)$ lower than that of the control in both trenching treatments. However, differences between tree species were not significant at $p=0.05$. Although, mung bean under the TR had higher $P$ than the corresponding NTR except in the crop with Desmodium (Table 1), the difference was not significant $(p=0.05)$. Different hedge species and trenching had highly significant $(p<0.0001)$ effects on plant $K$ contents. In both TR and NTR, mung bean with all tree species had significantly lower $\mathrm{K}$ than the sole crop. Among HI, mung bean with Gliricidia and Cassia had the highest and the lowest K (Table 1). TR significantly increased the $\mathrm{K}$ content of mung bean with all hedge species as compared to NTR.

Initial soil nutrients: Initial soil N, $\mathrm{P}$ and $\mathrm{K}$ showed highly significant $(\mathrm{p}<0.0001)$ variation between different hedgerow species (Table 2). Experimental plots which were under the sole crops in the previous season (and designated to have sole crops in the present season also) had significantly greater initial soil N, P and $K$ than all $\mathrm{HI}$ plots except those with Gliricidia. Plots with Gliricidia showed significantly greater initial soil nutrients than even the sole crop control. On the other hand, initial soil nutrient contents did not differ significantly $(p=0.05)$ between plots designated to have TR and NTR treatments. Initial soil nutrients did not differ 
Table 1: Major nutrient contents of mung bean grown with different hedgerow tree species with (TR) and without (NTR) trenching

\begin{tabular}{|c|c|c|c|c|c|c|}
\hline \multirow{2}{*}{$\begin{array}{l}\text { Tree } \\
\text { species }\end{array}$} & \multicolumn{2}{|c|}{ Nitrogen (\%) } & \multicolumn{2}{|c|}{$\begin{array}{c}\text { Phosphorus } \\
\text { (mg/100 g dry wt.) }\end{array}$} & \multicolumn{2}{|c|}{$\begin{array}{c}\text { Potassium } \\
(\mathrm{mg} / 100 \mathrm{~g} \text { dry wt. })\end{array}$} \\
\hline & $\mathrm{TR}$ & NTR & $\mathrm{TR}$ & NTR & TR & NTR \\
\hline Control & \multicolumn{2}{|c|}{1.059} & \multicolumn{2}{|c|}{187.33} & \multicolumn{2}{|c|}{75.22} \\
\hline Cassia & 0.752 & 0.613 & 124.44 & 112.22 & 41.00 & 33.33 \\
\hline Calliandra & 1.117 & 1.011 & 137.22 & 122.78 & 52.00 & 44.89 \\
\hline Gliricidia & 1.126 & 1.023 & 142.78 & 128.33 & 67.44 & 59.78 \\
\hline Flemingia & 0.957 & 0.938 & 124.44 & 105.56 & 52.78 & 46.00 \\
\hline Tithonia. & 1.074 & 0.994 & 117.78 & 107.78 & 56.89 & 42.67 \\
\hline Desmodium & 1.086 & 1.018 & 114.44 & 125.56 & 46.44 & 42.11 \\
\hline Mean & 1.024 & 0.951 & 135.49 & 127.08 & 55.97 & 49.14 \\
\hline $\begin{array}{l}\mathrm{SE} \\
(\mathrm{df}=18)\end{array}$ & \multicolumn{2}{|c|}{0.029} & \multicolumn{2}{|c|}{8.21} & \multicolumn{2}{|c|}{3.28} \\
\hline
\end{tabular}

Note: Each value is the mean of measurements at three distances from hedgerows (30, 180, and $360 \mathrm{~cm}$ ) in three replicate plots of each species $x$ trenching treatment combination.

Table 2: Soil nutrient contents at sowing of mung bean grown with different hedgerow tree species with (TR) and without (NTR) trenching

\begin{tabular}{|c|c|c|c|c|c|c|}
\hline \multirow{2}{*}{$\begin{array}{l}\text { Tree } \\
\text { species }\end{array}$} & \multicolumn{2}{|c|}{$\begin{array}{l}\text { Total N }(\%) \\
\quad\left(\times 10^{-2}\right)\end{array}$} & \multicolumn{2}{|c|}{$\begin{array}{c}\text { Available P } \\
(\mathrm{mg} / 100 \mathrm{~g})\end{array}$} & \multicolumn{2}{|c|}{$\begin{array}{c}\text { Available K } \\
(\mathrm{mg} / 100 \mathrm{~g})\end{array}$} \\
\hline & $\mathrm{TR}$ & NTR & TR & NTR & TR & NTR \\
\hline Control & \multicolumn{2}{|c|}{10.1} & \multicolumn{2}{|c|}{2.000} & \multicolumn{2}{|c|}{7.56} \\
\hline Cassia & 7.0 & 7.4 & 0.467 & 0.464 & 5.36 & 4.42 \\
\hline Calliandra & -7.6 & \multirow[t]{2}{*}{8.3} & 0.373 & 0.376 & 3.71 & 3.63 \\
\hline Gliricidia & 16.2 & & 2.294 & 2.321 & 10.78 & 10.83 \\
\hline Flemingia & 7.0 & 7.2 & 0.469 & 0.533 & 4.05 & 3.79 \\
\hline Tithonia & 7.4 & 7.2 & 0.368 & 0.438 & 4.78 & 5.21 \\
\hline Desmodium & 7.3 & 7.2 & 0.406 & 0.404 & 4.16 & 4.21 \\
\hline Mean & 8.9 & 9.1 & 0.911 & 0.934 & 5.77 & 5.67 \\
\hline $\begin{array}{l}\mathrm{SE} \\
(\mathrm{df}=36)\end{array}$ & \multicolumn{2}{|c|}{0.63} & \multicolumn{2}{|c|}{0.049} & \multicolumn{2}{|c|}{0.466} \\
\hline
\end{tabular}

Note: Each value is the mean over two soil depths and three distances from the hedgerows. See text for further explantation. 
significantly $(p=0.05)$ between top and sub-soil layers or between different distances from hedges (data not shown).

Soil nutrient contents at harvest of mung bean: Soil nutrient contents at harvesting of mung bean varied significantly with different tree species, trenching treatments, soil depth and distance from hedges. In order to retain clarity of presentation, effects of tree species and trenching are given in Table 3 and those of soil depth and distance from hedges are shown in Table 4. This separate presentation was possible because there was no significant $(p<0.05)$ interaction between the two above sets of factors.

Table 3: Soil nutrient contents at final harvest of mung bean grown with different hedgerow tree species with (TR) and without (NTR) trenching

\begin{tabular}{|c|c|c|c|c|c|c|}
\hline \multirow[t]{2}{*}{ Tree species } & \multicolumn{2}{|c|}{$\begin{array}{c}\text { Total N (\%) } \\
\left(\times 10^{-2}\right) \\
\end{array}$} & \multicolumn{2}{|c|}{$\begin{array}{l}\text { Available P } \\
(\mathrm{mg} / 100 \mathrm{~g})\end{array}$} & \multicolumn{2}{|c|}{$\begin{array}{c}\text { Available K } \\
(\mathrm{mg} / 100 \mathrm{~g})\end{array}$} \\
\hline & $\mathrm{TR}$ & NTR & $\mathrm{TR}$ & NTR & $\mathrm{TR}$ & NTR \\
\hline Control & \multicolumn{2}{|c|}{9.1} & \multicolumn{2}{|c|}{1.058} & \multicolumn{2}{|c|}{23.70} \\
\hline Cassia & 7.0 & 6.3 & 0.810 & 0.764 & 28.11 & 26.58 \\
\hline Calliandra & 7.4 & 5.1 & 0.797 & 0.641 & 28.24 & 27.21 \\
\hline Gliricidia & 8.5 & 8.1 & 1.178 & 0.941 & 32.27 & 30.44 \\
\hline Flemingia & 7.4 & 7.3 & 0.752 & 0.697 & 29.19 & 26.89 \\
\hline Tithonia & 6.7 & 5.2 & 0.758 & 0.690 & 28.84 & 26.54 \\
\hline Desmodium & 8.3 & 5.6 & 0.697 & 0.669 & 27.65 & 25.48 \\
\hline Mean & 7.8 & 6.7 & 0.864 & 0.780 & 28.29 & 26.69 \\
\hline $\mathrm{SE}(\mathrm{df}=36)$ & \multicolumn{2}{|c|}{0.35} & \multicolumn{2}{|c|}{0.049} & \multicolumn{2}{|c|}{0.669} \\
\hline
\end{tabular}

Note: Each value is the mean over two soil depths and three distances from the hedgerows. See text for further explanation.

In both TR and NTR treatments, soil $\mathrm{N}$ at harvest was significantly $(\mathrm{p}<0.01)$ lower than sole crop in all HI except those with Gliricidia (Table 3). While trenching increased final soil $\mathrm{N}$ in all $\mathrm{HI}$ as compared to the respective NTR treatments, the increases were most prominent in HI with Desmodium, Tithonia and Calliandra. The overall effect of trenching on final soil $\mathrm{N}$ was highly significant $(\mathrm{p}<0.0001)$. Similar to the pattern shown by soil $\mathrm{N}$, the final available soil $\mathrm{P}$ was significantly $(p<0.05)$ lower than in the sole crop in all HI except those with Gliricidia in both trenching treatments (Table 3$)$. Trenching significantly $(\mathrm{p}<0.0001)$ increased the final soil P in all HI with the greatest increases in HI with Gliricidia and Calliandra. Final soil exchangeable $\mathrm{K}$ showed a different pattern to those of $\mathrm{N}$ and $\mathrm{P}$ with all $\mathrm{HI}$ 
having significantly $(p<0.0001)$ greater final soil $K$ than the sole crop (Table 3$)$. Ir both trenching treatments, HI with Gliricidia had significantly greater final soil $\mathrm{F}$ than the rest which did not differ significantly $(\mathrm{p}<0.05)$ among themselves. Trenchin significantly $(\mathrm{p}<0.001)$ increased the final soil $\mathrm{K}$ in all $\mathrm{HI}$.

Soil $\mathrm{N}$ at harvest of mung bean increased significantly $(\mathrm{p}<0.0001)$ wit] increasing distance from hedges in both top soil $(0-10 \mathrm{~cm}$ depth) and sub-soi (20-40 cm depth) layers (Table 4). However, the respective final soil $\mathrm{N}$ did no differ significantly $(p<0.05)$ between the two soil layers. Similar to $\mathrm{N}$, both fina soil $P$ and $K$ increased significantly $(p<0.001)$ with increasing distance from hedge in both soil layers. In addition, the respective $\mathrm{P}$ and $\mathrm{K}$ were significantly greater is top soil as compared to sub-soil.

Table 4: Soil nutrient contents at final harvest of mung bean at differen distances from hedgerows in top soil $(0-10 \mathrm{~cm}$ depth) and sub-soil $(20-40 \mathrm{~cm}$ layers

\begin{tabular}{|c|c|c|c|c|c|c|}
\hline \multirow[t]{2}{*}{ Distance (m) } & \multicolumn{2}{|c|}{$\begin{array}{c}\text { Total N }(\%) \\
\left(\times 10^{-2}\right) \\
\end{array}$} & \multicolumn{2}{|c|}{$\begin{array}{c}\text { Available P } \\
(\mathrm{mg} / 100 \mathrm{~g})\end{array}$} & \multicolumn{2}{|c|}{$\begin{array}{c}\text { Available K } \\
(\mathrm{mg} / 100 \mathrm{~g})\end{array}$} \\
\hline & Top & Sub & Top & Sub & Top & $\mathrm{Sr}$ \\
\hline 0.15 & 5.8 & 5.5 & 0.821 & 0.700 & 26.33 & 22.8 \\
\hline 1.65 & 7.3 & 7.5 & 0.880 & 0.731 & 29.51 & 26. \\
\hline 3.15 & 8.4 & 8.8 & 0.943 & 0.857 & 31.80 & 27. \\
\hline Mean & 7.2 & 7.3 & 0.881 & 0.763 & 29.21 & 25. \\
\hline $\mathrm{SE}(\mathrm{df}=36)$ & \multicolumn{2}{|c|}{0.33} & \multicolumn{2}{|c|}{0.045} & \multicolumn{2}{|c|}{0.62} \\
\hline
\end{tabular}

Note: Each value is the mean over six tree species and two trenching treatments. See text for furth explanation.

Changes in soil nutrients during the cropping season: Table 5 shows th changes in major soil nutrients during the cropping season. In TR treatments, $\mathrm{F}$ with Desmodium and Flemingia showed increases in total soil $\mathrm{N}$ whereas the re of $\mathrm{HI}$ and the sole crop showed decreases in soil N. Soil N depletion under TR w: highest in HI with Gliricidia and least in HI with Cassia and Calliandra. Und NTR, all HI except that with Flemingia showed depletion of soil N which was great than the respective depletion under TR. Here also, the highest $\mathrm{N}$ depletion $\mathrm{w}$ shown by HI with Gliricidia and the least was by HI with Cassia. In contrast to soil $\mathrm{K}$ showed an increase in all $\mathrm{HI}$ and the sole crop under both $\mathrm{TR}$ and NT treatments (Table 5). Moreover, all HI had greater $\mathrm{K}$ enrichment than so crop under both trenching treatments. On the other hand, trenching slight increased the respective soil $\mathrm{K}$ enrichment in all HI. Soil P also showed 
enrichment during the season in all HI except those with Gliricidia. In contrast, there was a soil $\mathrm{P}$ depletion in sole crops. Trenching increased $\mathrm{P}$ enrichment in all HI where there was an enrichment and decreased P depletion in the rest. Highest $\mathrm{P}$ enrichment was shown in HI with Cassia (in TR) and Gliricidia (in NTR).

Table 5: Changes in soil nutrient contents during the cropping season of mung bean grown with different hedgerow tree species with (TR) and without (NTR) trenching

\begin{tabular}{|c|c|c|c|c|c|c|}
\hline \multirow[t]{2}{*}{ Tree species } & \multicolumn{2}{|c|}{$\begin{array}{c}\text { Total N }(\%) \\
\left(\times 10^{-3}\right) \\
\end{array}$} & \multicolumn{2}{|c|}{$\begin{array}{c}\text { Available P } \\
(\mathrm{mg} / 100 \mathrm{~g})\end{array}$} & \multicolumn{2}{|c|}{$\begin{array}{c}\text { Availabe K } \\
(\mathrm{mg} / 100 \mathrm{~g})\end{array}$} \\
\hline & $\mathrm{TR}$ & NTR & $\mathrm{TR}$ & NTR & TR & NTR \\
\hline Control & \multicolumn{2}{|c|}{-10.0} & \multicolumn{2}{|c|}{-0.942} & \multicolumn{2}{|c|}{16.14} \\
\hline Cassia & -0.4 & -10.8 & 0.343 & 0.265 & 22.75 & 22.16 \\
\hline Callianda & -1.9 & -32.1 & 0.424 & 0.300 & 24.53 & 23.49 \\
\hline Gliricidia & -76.9 & -80.1 & -1.116 & -1.380 & 21.50 & 19.61 \\
\hline Flemingia & 4.4 & 1.0 & 0.283 & 0.164 & 25.14 & 23.10 \\
\hline Tithonia & -6.9 & -20.4 & 0.390 & 0.252 & 24.06 & 21.33 \\
\hline Desmodium & 9.9 & -15.2 & 0.291 & 0.265 & 23.49 & 21.27 \\
\hline
\end{tabular}

Note: Each value is the difference between the respective values at harvest (Table 3 ) and sowing (Tahle 2) of mung bean. A negative value indicates nutrient depletion and a positive value indicates nutrient enrichment

Radiation interception: The fraction of incoming radiation intercepted (R), at both $15\left(R_{15}\right)$ and $200\left(R_{200}\right) \mathrm{cm}$ distances from hedges, showed significant $(p<0.0001)$ variation between different tree species on all dates of measurement (Fig. 1.a \& b) with the exception of $R_{200}$ at 6 weeks after sowing (WAS). The inter-species variation was clearer at $15 \mathrm{~cm}$ from hedges than at $200 \mathrm{~cm}$. Except for HI with Flemingia and Desmodium, all other HI had significantly $(p<0.05)$ greater $\mathrm{R}_{15}$ throughout the duration of measurement. HI with Tithonia had significantly $(p<0.05)$ greater $R_{15}$ than the rest from 6 WAS onwards. HI with Cassia, Gliricidia and Calliandra also had significantly $(p<0.05)$ greater $R_{15}$ than the sole crop throughout the measurement period. In general, $R_{200}$ was lower than $R_{15}$ in all $H I$ throughout the season. However, inter-species variation of $R_{200}$ (Fig. 1.b) was less consistent as compared to $R_{15}$ (Fig. 1.a). During the first 4 weeks, sole crops had significantly $(p<0.05)$ greater or equal $R_{200}$ than all HI. At 6 WAS, $R_{200}$ of all HI did not differ significantly $(p<0.05)$ from the sole crop. From then onwards, HI with Tithonia had significantly $(p<0.05)$ greater $R_{200}$ than all other crops including the control. Among the rest of HI, those with Cassia, Gliricidia and Calliandra had significantly $(\mathrm{p}<0.05)$ greater $\mathrm{R}_{200}$ than those with Flemingia and Desmodium. 


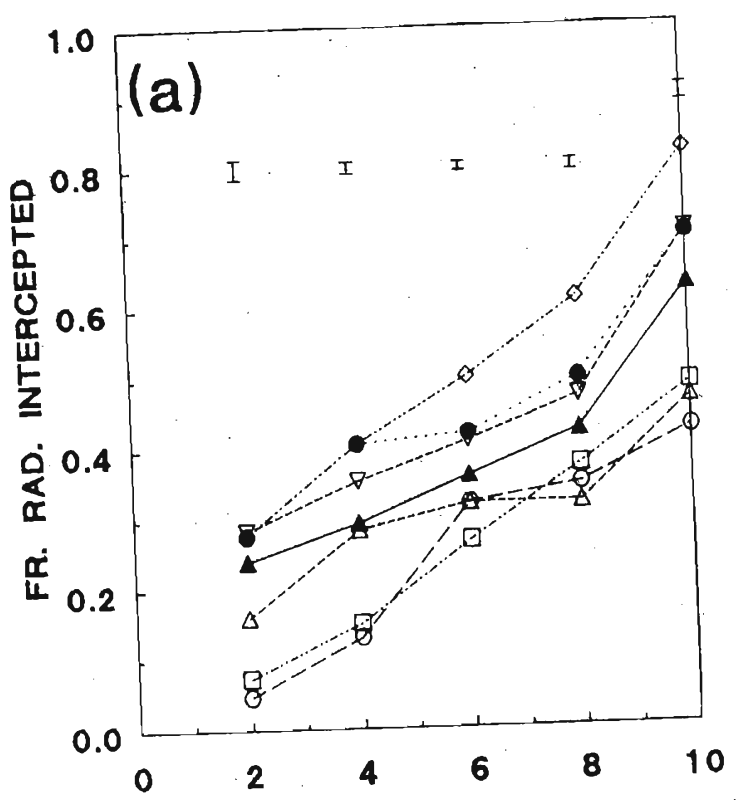

WEEKS AFTER SOWING

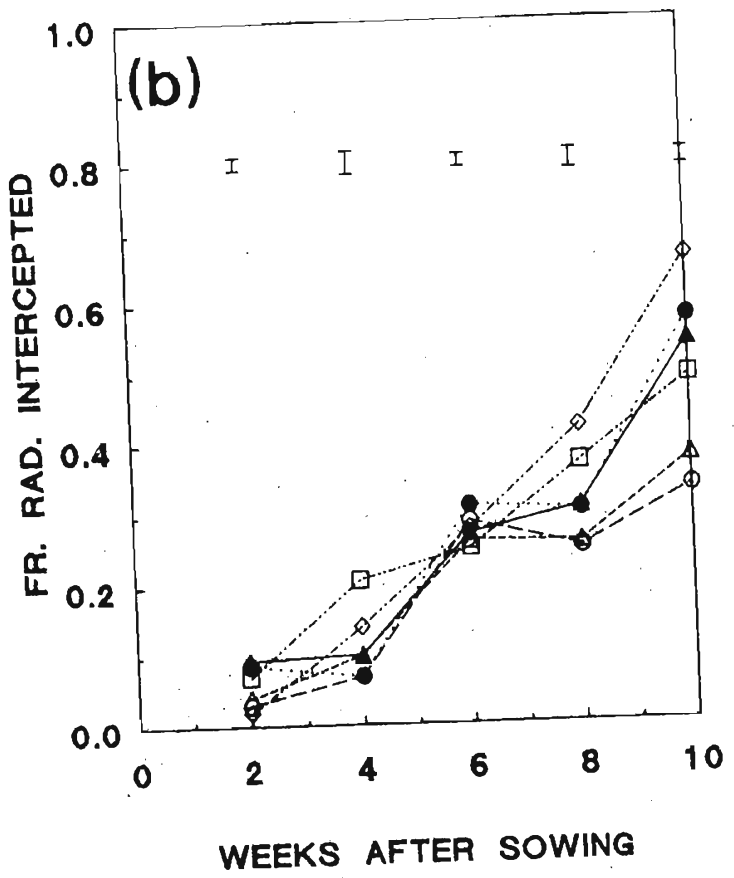

Figure 1: Variation of the fraction of radiation intercepted under different tree species at (a) $15 \mathrm{~cm}$ and (b) $200 \mathrm{~cm}$ from hedgerows. $\Delta$-Calliandra; $\triangle$-Desmodium;-O - Flemingia; -Gliricidia; $\diamond$ - Tithonia; $\nabla$ - Cassia; $\square$ - Control. Vertical bars indicate standard errors (d.f. $=3$ ). 
(a) $0-10 \mathrm{~cm} \mathrm{DEPTH}$ WITH TRENCHING

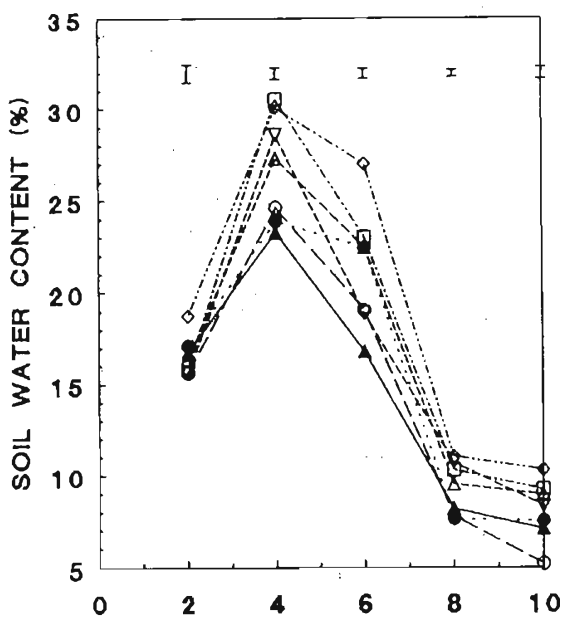

WEEKS AFTER SOWING

(c) $20-40 \mathrm{~cm}$. DEPTH WITH TRENCHING

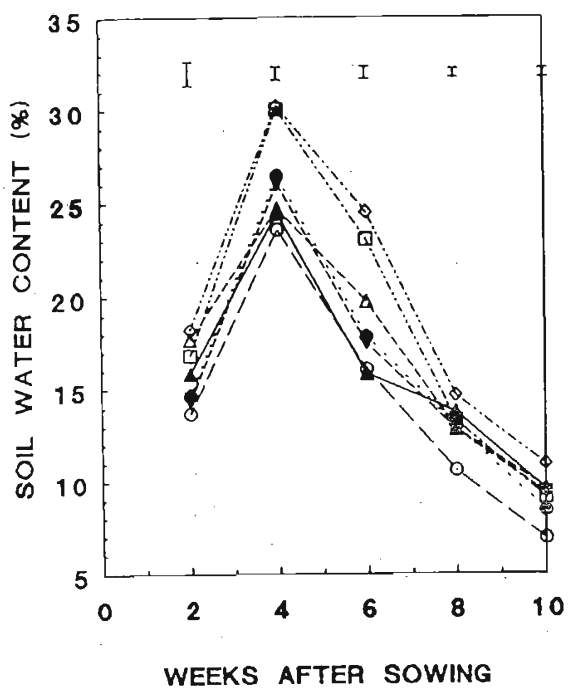

(b) $0-10 \mathrm{~cm} \mathrm{DEPTH}$

WITHOUT TRENCHING

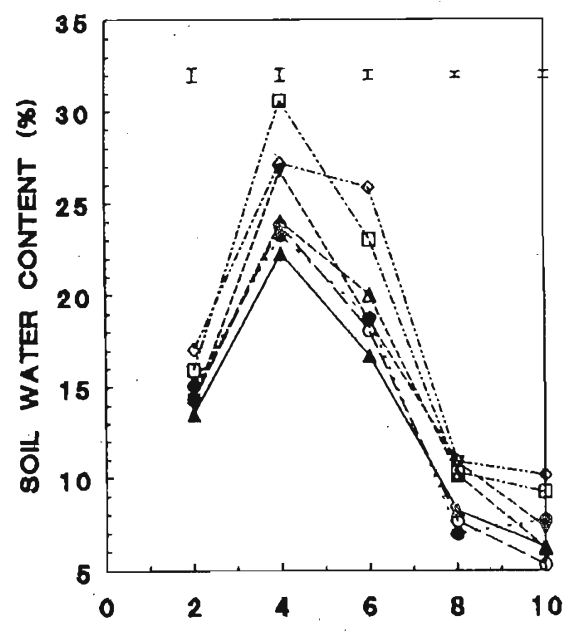

WEEKS AFTEF SOWING

\section{WITHOUT TRENCHING}

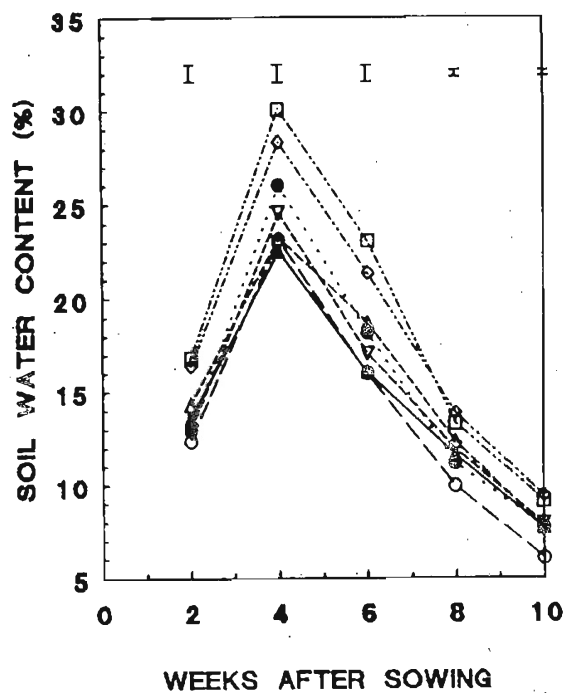

Figure 2: Variation of soil water content (\% dry basis) at $0-10 \mathrm{~cm}$ (top soil) and $20-40 \mathrm{~cm}$ (sub-soil) depths under different hedgerow species with and without trenching. $\Delta$-Calliandra; $\triangle$-Desmodium; O- Flemingia; - Gliricidia; $\diamond$ - Tithonia; $\nabla$-Cassia; $\square$-Control. Vertical bars indicate standard errors at degrees of freedom of 6 . 
Table 6: Seasonal variation of soil water contents (\% dry weight basis) at different distances from hedgerows in top soil ( 0-10 cm depth) and sub-soil $(20-40 \mathrm{~cm})$ layers for treatments with (TR) and without (NTR) trenching.

\begin{tabular}{lccllc}
\hline $\begin{array}{l}\text { Weeks } \\
\text { after } \\
\text { sowing }\end{array}$ & $\begin{array}{c}\text { Distance } \\
\text { from hedge } \\
(\mathrm{cm})\end{array}$ & \multicolumn{2}{c}{ Top soil } & \multicolumn{2}{c}{ Sub soil } \\
\cline { 3 - 6 } 2 & 15 & 19.31 & $16.21 \dagger$ & 16.84 & $14.11 \dagger$ \\
& 200 & $13.89^{*}$ & $13.64^{*} \mathrm{~ns}$ & $14.98 \mathrm{~ns}$ & $14.25 \mathrm{~ns} n \mathrm{~s}$ \\
4 & 15 & 26.41 & $24.53 \dagger$ & 26.02 & $24.69 \dagger$ \\
& 200 & $27.43^{*}$ & $26.24^{*} \dagger$ & $27.03 \mathrm{~ns}$ & $26.09 \mathrm{~ns} n s$ \\
6 & 15 & 21.31 & $20.12 \dagger$ & 18.89 & $18.13 \mathrm{~ns}$ \\
& 200 & $21.48 \mathrm{~ns}$ & $20.12 \mathrm{~ns} \dagger$ & $19.54 \mathrm{~ns}$ & $19.08 \mathrm{~ns} n \mathrm{~s}$ \\
& 15 & 10.08 & $9.96 \mathrm{~ns}$ & 14.47 & $12.93 \dagger$ \\
& 200 & $8.51^{*}$ & $8.60^{*} \mathrm{~ns}$ & $11.52^{*}$ & $11.09^{*} \mathrm{~ns}$ \\
& 15 & 8.74 & $8.00 \mathrm{~ns}$ & 10.17 & $8.39 \dagger$ \\
& 200 & $7.42^{*}$ & $6.89^{*} \mathrm{~ns}$ & $8.06^{*}$ & $7.46^{*} \mathrm{~ns}$ \\
\hline
\end{tabular}

Note: Each value is the mean of 6 tree species (plus control) and 3 replicates. Significance (or otherwise) of mean comparisons between distances within each trenching treatment is shown by (or ns). Significance (or otherwise) of mean comparisons between trenching treatments within each distance is shown by $\dagger(0 x \cdot n, s)$.

Soil water content (SWC): Seasonal variation of SWC in top and sub-soil layers with (TR) and without (NTR) trenching is shown in Fig. 2. There was a common overall pattern with SWC increasing up to 4 WAS and then decreasing until. harvest of mung bean. The substantial rainfall that occurred during the initial 4 week period after sowing (as shown in Table 1 of the companion paper ${ }^{4}$ ) was responsible for the increase in SWC up to 4 WAS. A notable feature in the seasonal variation of SWC in both HI and sole crop plots was that the decrease of SWC in top soil was substantially reduced during the final 2 week period from 8 to 10 WAS (Fig. 2. a \& b). This was probably because of the decrease in water use by mung bean during this final phase. In contrast, soil water extraction from the sub-soil layer during the final fortnight continued at almost the same rate as before. Except at 2 WAS, there were highly significant $(p<0.0001)$ differences between hedgerow species in SWC in both soil layers as well as in both TR and NTR (Fig. 2). In general, on most days of measurement in all four treatment combinations ( 2 soil layers $\mathrm{x} 2$ trenching treatments), the sole crop had significantly greater SWC than all HI except Tithonia. On some days (eg. at 6 WAS in top soil), HI with Tithonia had significantly greater SWC than even the sole crop. In the top soil, HI with 
Calliandra, Gliricidia and Flemingia tended to have lower SWC under both TR and NTR whereas HI with Cassia and Desmodium tended to have higher SWC. HI with Tithonia had significantly $(\mathrm{p}<0.05)$ greater sub-soil SWC as compared to the rest of HI. On the other hand, HI with Flemingia had significantly lower sub-soil SWC on most days under both TR and NTR. Although not apparent in Fig. 2 , trenching increased SWC in both top and sub-soil layers.

Table 6 shows the effect of trenching and distance from hedgerow (D) on top and sub-soil SWC. Trenching significantly $(\mathrm{p}<0.0001)$ increased SWC in both top soil (except at 8 WAS) and sub-soil (except at 6 WAS). Except at 6 WAS, D had a significant $(p<0.05)$ effect on top soil SWC in both TR and NTR. At 2, 8 and 10 WAS, top soil SWC was significantly higher closer to the hedgerow (at $15 \mathrm{~cm}$ ) whereas the opposite was observed at 4 WAS (Table 6). In contrast to top soil, D did not have a significant $(\mathrm{p}<0.05)$ effect on sub-soil SWC on 2, 4 and 6 WAS. However, at 8 and 10 WAS, sub-soil SWC was significantly greater at $15 \mathrm{~cm}$ than at $200 \mathrm{~cm}$ in both TR and NTR.

\section{DISCUSSION}

Plant and soil nutrient contents: Comparison of plant nutrient contents between sole crops and HI indicated whether the presence of hedges increased or decreased the availability of respective nutrients to mung bean. This experiment clearly showed that hedges decreased the availability of all three major nutrients $(\mathrm{N}, \mathrm{P} \& \mathrm{~K})$ to mung bean. The fact that this was due to competitive absorption of nutrients by hedgerow roots was confirmed by the trenching treatment (TR) which showed increased nutrient availability as compared to the non-trenching treatment (NTR). Although competition for N and $\mathrm{K}$ could be removed quickly by trenching (as shown by significant increases in TR), results of this work indicate that competition for $\mathrm{P}$ may not be readily removed by trenching (as shown by small, statistically non-significant increases in TR). Gunasena et al. ${ }^{12}$ also observed that HI decreased the availability of available $P$ in both the top $(0-10 \mathrm{~cm})$ and sub-soil $(10-40 \mathrm{~cm})$ layers. However, these observations contradicted the findings of Haggar et al. ${ }^{13}$, Hands et al. ${ }^{14}$ and Hulugalle and $\mathrm{Ndi}^{15}$ that $\mathrm{HI}$ increased plant available P. Differences between hedge species clearly indicated that competition for nutrients (especially for $\mathrm{N}$ and $\mathrm{K}$ ) was least by Gliricidia and highest by Cassia. In fact, the variation in plant nutrients observed in our experiment is due to the net result of two opposing effects, i.e. the competitive removal of nutrients by hedgerow roots and addition of nutrients through hedge prunings. Therefore, the high level of competition by Cassia could be either due to its higher root competition or lower nutrient additions through prunings. It is likely that both the above factors were responsible. Cassia had the highest above-ground biomass production among the tree species ${ }^{4}$ and therefore could be expected to exert greater competition for nutrients and also have án extensive root system. ${ }^{16}$ Rao et al. ${ }^{17}$ observed that the root system of Gliricidia in hedgerow 
intercrops was less extensive than that of Cassia, thus confirming our observation of greater root competition by Cassia. Moreover, as biological $\mathrm{N}_{2}$ fixation does not occur in Cassia, it is likely to have less $\mathrm{N}$ in its prunings.

The above conclusions based on observed variation of plant nutrient contents were confirmed by soil nutrient contents. Greater removal of soil N, P and K by HI was confirmed by the significantly lower initial values of $N$ and $K$ in $H I$ as compared to sole crops. Moreover, the lower competition from Gliricidia was confirmed by the significantly greater initial soil N, P and K contents in plots with Gliricidia as compared to other tree species. The lower final soil $\mathrm{N}$ and $\mathrm{P}$ contents in $\mathrm{HI}$ as compared to sole crops and increased final soil $\mathrm{N}, \mathrm{P}$ and $\mathrm{K}$ contents with trenching further confirmed the root competition for nutrients in HI. The highest values of final soil N, P and K in HI with Gliricidia further confirmed its lower level of competition for nutrients.

On the other hand, a notable finding of our experiment is the ability of all hedgerow species to enrich soil $\mathrm{K}$ during the course of the cropping season. A similar observation was made by Salazar et al. ${ }^{18}$ and in the previous season of this work which was not reported in De Costa and Chandrapala ${ }^{6}$ because of the need to confirm it. This increase in soil $\mathrm{K}$ could have been caused by the release of $\mathrm{K}$ due to fine root turnover during the cropping season and especially at its beginning when hedges were pruned. Moreover, some of the $\mathrm{K}$ fixed within clay minerals could have been released to the soil solution during the cropping season ${ }^{19}$ and this process could have been facilitated by hedge root systems. However, significantly greater plant $K$ contents in sole crops than in HI, show that despite the increased availability of $\mathrm{K}$ in the soil, mung bean in $\mathrm{HI}$ faced competition from tree roots during absorption of $\mathrm{K}$. This was confirmed by the significantly greater $\mathrm{K}$, in both plants and soil at harvest, in trenched plots. Here again, Gliricidia showed the lowest competition. The observation of Schroth and Zech" and Rao et al. ${ }^{27}$ that Gliricidia has a lower capacity for root production as compared to most hedgerow species could explain its low competition in the present experiment. Further evidence to demonstrate the significant root competition from hedgerows for all major nutrients is provided by the observations of increased availability of $\mathrm{N}, \mathrm{P}$ and $\mathrm{K}$ with increasing distance from hedgerows.

Another notable observation was the absence of significant differences in plant nutrient contents at different distances from hedgerows despite significant variation in soil nutrient contents with distance from hedgerows (Table 4). This was probably because the hedgerow roots had spread the entire width of the alley between the two hedges and were competitively absorbing more nutrients from the soil. Recently, many workers ${ }^{5,21,22}$ have observed that after a few years from establishment, the hedgerow roots traverse the whole width of the alley. If this occurs and if the hedgerow roots can competitively absorb more nutrients, it is not surprising that the plant nutrient contents within the alley do not vary significantly with distance from the hedgerow. 
Radiation interception: Results on inter-species variation of the fraction of radiation intercepted ( $R$ ) showed that hedges exerted significant competition for light as shown by the greater $\mathrm{R}$ at $15 \mathrm{~cm}$ from the hedge (where both the hedge and crop would intercept radiation) than at $200 \mathrm{~cm}$ (where only the crop would intercept radiation). As all hedgerow intercrops grew taller than mung bean, it is highly likely that a greater proportion of the increased $R_{15} \mathrm{~cm}$ was being intercepted by hedge rather than crop. This was confirmed by the highest $\mathrm{R}_{1,5}$ in HI with Tithonia (which had the 'most-spreading' canopy) and the low $\mathrm{R}_{15}$ in HI with Flemingia and Desmodium. (which had the 'least-spreading' canopies). Corlett et al. ${ }^{5}$ also observed greater shading of annual crops when canopies of hedges were allowed to spread by less frequent pruning.

Soil water contents (SWC): The generally higher SWC in sole crops than in $\mathrm{HI}$ indicated that there was significant competition for soil water from hedge roots. This was confirmed by the increase of SWC with trenching. Similar positive effects were observed with root barriers by Ong et al. ${ }^{2: 3}$ and Rao et al. ${ }^{24}$ Hauser and Gichuru ${ }^{2 \pi}$ also observed significant competition for water by hedges of Cassia and Acioa. However, hedges had a positive effect in conserving soil water, especially in top soi] near hedges by their shading effect which probably minimized soil evaporation and crop transpiration. This is supported by the significantly greater SWC observed in HI with Tithonia which probably exerted the highest shading effect due to its spreading canopy. Chirwa et al..$^{26}$ also observed a positive effect of HI which had a lower soil water suction than sole crops.

This work clearly showed that tree roots of hedgerow intercrops exerted significant competition with the annual crop for absorption of nutrients and water. However, tree species differed in the degree of competition exerted. In the present environment, out of the tree species tested, Gliricidia exerted the least competition for nutrients while Tithonia exerted the least competition for water.

\section{Acknowledgement}

This research was funded by the International Foundation for Science, Sweden with the advice of Dr. C.K. Ong (International Center for Research with Agroforestry, Nairobi, Kenya). Assistance of K.B. Attanayake (Department of Crop Science) and Dr. M. Herath and his staff of the Environment and Forestry Division of Mahaweli Authority is gratefully acknowledged.

\section{References}

1. Rao M.R., Nair P.K.R. \& Ong C.K. (1998). Biophysical interactions in tropical agroforestry systems. Agroforestry Systems 38: 3-50. 
2. Ong C.K. (1991). The interactions of light, water and nutrients in agroforestry systems. In: Biophysical Research for Asian Agroforestry (Eds. M.E. Avery, M.G.R. Cannell \& C.K. Ong) pp. 107-124. Winrock International, USA Oxford \& IBH, India.

3. Sanchez P.A. (1995). Science in agroforestry. Agroforestry Systems 30: 5-55.

4. De Costa W.A.J.M. \& Chandrapala A.G. (2000a). Partitioning of above- and below-ground competition of different hedgerow tree species on mung bean (Vigna radiata (L.) Wilczek) in the mid-country intermediate zone of Sri. Lanka. Journal of the National Science Foundation of Sri Lanka 28(2): 113-125.

5. Corlett J.E., Black C.R., Ong C.K. \& Monteith J.L. (1992a). Above and. below-ground interactions in a Leucaena/millet alley cropping system. II. Light interception and dry matter production. Agricultural and Forest Meteorology 60: 73-91.

6. De Costa W.A.J.M. \& Chandrapala A.G. (2000b). Environmental interactions between different tree species and mung bean (Vigna radiata (L.) Wilczek) in hedgerow intercropping systems in Sri Lanka. Journal of Agronomy and Crop Science 184: 145-152.

7. Singh R.P., Ong C.K. \& Saharan N. (1989). Above and below-ground interactions in alley cropping in semi-arid India. Agroforestry Systems 9: $259-274$.

8. Szott L.T., Fernandes E.C.M. \& Sanchez P. (1991). Soil-plant interactions in agroforestry systems. Forest Ecology and Management 45: 127-152.

9. Hesse, P.R. (1971). A textbook of soil chemical analysis. John Murray, London.

10. Davidescu D. \& Davidescu V. (1982). Evaluation of fertility by plant and soil analysis. Abacus Press, UK.

11. Anderson J.M. \& Ingram J.S.I. (1993). Tropical soil biology and fertility: a handbook of methods. 2nd Edition. CAB International, UK.

12. Gunasena H.P.M., Mapa R.B., Pushpakumara D.K.N.G. \& Hitinayake H.M.G.S.B. (1991). Effect of alley cropping on soil physical and chemical properties in the mid-country intermediate zone. In: Proceedings of the Second Regional Workshop on Multipurpose Tree Species, 5-7 April, 1991, Kandy, Sri Lanka (Ed. H.P.M. Gunasena) pp. 107-124. MPTS Research Network, Sri Lanka. 
13. Haggar J.P., Warren G.P., Beer J.W. \& Kass D. (1991). Phosphorus availability under alley cropping and mulched and unmulched sole cropped systems in Costa Rica. Plant and Soil 137: 275-283.

14. Hands M.R., Harrison A.F. \& Bayliss-Smith T. (1995). Phosphorus dynamics in slash-and-burn and alley cropping systems of the humid tropics. In: Phosphorus in the global environment: transfers, cycles and management. (Ed. H. Tiessen) pp. 155-170. John Wiley, New York.

15. Hulugalle N.R. \& Ndi J.N. (1994). Changes in soil properties of a newlycleared Ultisol due to establishment of hedgerow species in alley cropping systems. Journal of Agricultural Science, Cambridge 122: 435-443.

16. Ong C.K., Black C.R., Marshall F.M. \& Corlett J.E. (1996). Principles of resource capture and utilization of light and water. In: Tree-crop interactions: a physiological approach (Eds. C.K. Ong \& P. Huxley) pp. 73-158. CAB International, UK.

17. Rao M.R., Muraya P. \& Huxley P.A. (1993). Observations of some tree root systems in agroforestry intercrop situations, and their graphical representation. Experimental Agriculture 29: 183-194.

18. Salazar A., Szott L.T. \& Palm C.A. (1993). Crop-tree interactions in alley cropping systems on alluvial soils of the Upper Amazon Basin. Agroforestry Systems 22: 67-82.

19. Foth H.D. \& Ellis B.G. (1988). Soil Fertility. John Wiley \& Sons, New York.

20. Schroth G. \& Zech W. (1995). Above- and below-ground biomass dynamics in a sole cropping and an alley cropping system with Gliricidia sepium in the semi-deciduous rainforest zone of West Africa. Agroforestry Systems 31: 181-198.

21. Hauser S. (1993). Root distribution of Dactyladenia (Acioa) barteri and Senna (Cassia) siamea in alley cropping on Ultisol. I. Implication for field experimentation. Agroforestry Systems 24: 111-121.

22. Ong C.K. (1994). Alley cropping - ecological pie in the sky ? Agroforestry Today 6 (3): 8-10.

23. Ong C.K., Corlett J.E., Singh R.P. \& Black C.R. (1991). Above and below ground interactions in agroforestry systems. Forest Ecology and Management 45: $45-57$. 
24. Rao M.R., Sharma M.M. \& Ong C.K. (1991). A tree/crop interface design and its use for evaluating the potential of hedgerow intercropping. Agroforestry Systems 15: 143-158.

25. Hauser S. \& Gichuru M.P. (1994). Root distribution of Dactyladenia (Acioa) barteri and Senna (Cassia) siamea in alley cropping on Ultisol.II Impact on water regime and consequences for experimental design. Agroforestry Systems 26: 9-21.

26. Chirwa P.W., Nair P. K. R. \& Nkedi-Kizza P. (1994). Pattern of soil moisture depletion in alley cropping under semiarid conditions in Zambia. Agroforestry Systems 26: 89-99 